\title{
ポリビニルアルコール皮膜の熱拠理による結晶化の検討†
}

(昭 和 36 年 1 月 31 日受 理)

$$
\text { 井 本 三 郎* }
$$

ポりビニルアルコール (PVA) 皮膜の熱処理を $120^{\circ} \mathrm{C}$ から $195^{\circ} \mathrm{C}$ の間で行ない, 過ヨウ素酸処理した後の膨潤度, 溶解度を測定した結果，熱処理による結晶化は主として熱処理前にすでに存在している微結晶を核として成長が行なわれ ると推定された。

また PVA の皮膜を $30^{\circ} \mathrm{C}$ から $80^{\circ} \mathrm{C}$ の間の温度で作製しそれを熱処理した場合，製膜温度の上年とともに膨潤度は小 さくなる。

これは熱処理前の微結晶の分布が同一繁処理温度で受ける結晶化を支配していると考えられる。さらにこれらの皮膜ま たは㵶維の整処理物の過ヨウ装酸処理後の溶解度を定量的に検討した結果, 過ヨウ素酸処理を施したPVA は非晶領域に

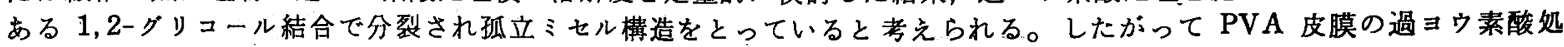
理した後の膨潤度, 溶解度は微結晶の発生状態と特に密接な関係にあり, ラテラルオーがーの間接的な目安になると考え られる。この結果過ヨウ素酸処理した後, 種々のフェノール濃度の溶液で分別溶解し, フェノール濃度に応じたラテラル オーダー分布を測定することが可能となり，熱処理 PVA の微細組辅を具体的にあらわすことがでるようになった。

\section{1 暒言}

ポリビニルアルコール (PVA) 皮膜を室温（約 $20^{\circ} \mathrm{C}$ ) そ $50^{\circ} \mathrm{C}$ で作製した場合で，その熱処理後の fine texture が相違してい ることを過ヨウ素酸処理した後の膨潤度, 溶解度の湘定より明ら かにしだ。

これは微結晶核の発生の仕方と分布によってその最終的な微細 組織は支配されるという高柳ら²)見解そ一致するものである。 著者は以上の見地より PVA の熱処理による結晶化の過程を検討 した。すなわち PVAの熱処理は既存の微結晶を核として成長が 行なわれ，熱処理の際の微結晶の.核間距離によりその fine texture は規定されるであろち。また PVA の構造上の規則性は核 の発生とその成長の両方に支配的に働いていると考えられる。そ れゆえ過ヨウ素酸処理後の膨潤度, 溶解度は微結晶の長さ, した がって微結晶の発生状態と特に密接な関係があり，かつラテラル オ言がーの間接的な目安になるのではないかと思われる。このよ ろ微結晶の発生が核生成機構によるるのであり，これによって 定まる微結晶の空間分布が高分子の微細組織に支配的な影響をむ つことは明らかになったが，それらの具体的な微細組織は何ら明 らかでない。

一方, 結晶性高分子固体を簡単に完全な結晶部分と非晶部分の 二部分からなっていると考えることは余りにる単純化されたるの であり，真の姿を示したものといえない。これらのことは一般的 に認められているところであり，これに対する種々な研究結果も 山る ${ }^{2,3)}$ 。結晶性高分子には完全な結晶部分と完全な非結晶部分 との間に連続的な各種段階の凝集状態が存在し，その凝集の強さ は側面活性基間の相互作用に基つく側面方向の凝集様式，すなわ ちラテラルオーダー（LO）によって規定され，結局 LO 分布は

$†$ 本研究を「過ヨウ素酸処理したポリビニルアルコール皮膜 の膨潤性（第 3 報）」とする.

* 倉敖レイヨン株式会社研究所 : 倉敫市酒津.

1) 井本, 浮田, 高分子化学 16，340 (1959).

2) 高柳, 石田, 昭和 32 年度高分子討論会 (1957, 10月, 於 名古屋).

3）たとえば J.A. Howsman, W. A. Sisson, “Cellulose and Cellulose derivatives" Part I, 231 (1954) ; K. Schmieder, K. Wolf, Kolloid-Z. 134, 149 (1953).
その微細組織を決定寸る要因であると考えられる。セルロースに ついてはこの点に関してかなり詳細に検討されており, 同様な概 念が結晶性高分子一般に適用されるはずであるが，現在他の高分 子物につい:ての実験例は極めて少ない行。

著者は LO の分布が PVA 熱処理物の 微細組織を規定する主 要な因子である以上これを測定しそれと性質との関連を明らか にすることは，重要なことであるので LO 分布の 測定法を検討 した。

以下これらの点について述べ。

\section{2 実験結果ならびに考察}

PVA 皮膜の過ヨウ素酸処理後の膨潤度, 溶解度の測定は, 既 報1)に記載したと同様な方法であり, 過ヨウ素酸ソーダ $\left(\mathrm{NaIO}_{4}\right)$ を用いて実験した。

実験に供した試料の重合条件ならびにえられた PVAの重合度 は表 1 のと括りである。表 1 の試料, No. $1 \sim 5$ を $30^{\circ} \mathrm{C}$ で製膜 し, $120^{\circ} \mathrm{C}$ で 1 時間, $140^{\circ} \mathrm{C}$ て 30 分間, $170^{\circ} \mathrm{C}$ で 10 分間, 195

表 1 VAc の重合条件とえられた PVA

\begin{tabular}{|c|c|c|c|c|c|}
\hline No. & 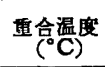 & \multicolumn{2}{|c|}{ 重合形式 } & $\begin{array}{l}\text { 重含鄞 } \\
\text { (\%) }\end{array}$ & $\overline{\boldsymbol{P}}_{\mathrm{A}}$ \\
\hline 1 & 60 & 塊 & 状 & 61 & 4335 \\
\hline 2 & 30 & 塊 & 状 & 79 & 6460 \\
\hline 3 & 0 & \multicolumn{2}{|c|}{ メタノール8\% 容液 } & 23 & 2400 \\
\hline 4 & -40 & 塊 & 状 & 17 & 4150 \\
\hline 5 & -78 & 塊 & 状 & 17 & 840 \\
\hline 6 & 60 & 塊 & 状 & 60 & 3935 \\
\hline 7 & 60 & 塊 & 状 & 90 & 3170 \\
\hline 8 & 30 & 塊 & 状 & 61 & 6380 \\
\hline 9 & $0 \sim 5$ & 塊 & 状 & 52 & - \\
\hline 10 & -20 & \multicolumn{2}{|c|}{ メタノール $8 \%$ 浴 } & 42 & 5060 \\
\hline
\end{tabular}

表 $230^{\circ} \mathrm{C}$ 製膜 PVA の種々の熱処理温度変化に 対する過 ヨウ素酸処理後の膨潤度, 溶解度

\begin{tabular}{|c|c|c|c|c|c|c|c|c|}
\hline & $120^{\circ} \mathrm{C}$, & $1 \mathrm{hr}$ & $140^{\circ} \mathrm{C}$, & $30 \mathrm{~min}$ & $170^{\circ} \mathrm{C}$, & $10 \mathrm{~min}$ & $195^{\circ} \mathrm{C}$, & $2 \mathrm{~min}$ \\
\hline 料番号 & 膨潤度 & $\begin{array}{c}\text { 溶解度 } \\
(\%)\end{array}$ & 膨潤度 & $\begin{array}{c}\text { 溶解度 } \\
(\%)\end{array}$ & 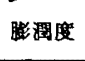 & $\begin{array}{c}\text { 荅解度 } \\
(\%)\end{array}$ & 瞅䎑度 & $\begin{array}{c}\text { 溶解度 } \\
(\%)\end{array}$ \\
\hline 1 & 2.03 & 52.0 & 1.05 & 33.9 & 0.59 & 18.5 & 0.61 & 20.2 \\
\hline 2 & 1.49 & 37.1 & 0.77 & 19.9 & 0.48 & 9.9 & 0.46 & 13.3 \\
\hline 3 & 1.12 & 25.2 & 0.60 & 9.9 & 0.32 & 3.6 & 0.42 & 8.6 \\
\hline 4 & 0.87 & 10.4 & 0.64 & 8.7 & 0.30 & 0 & 0.34 & 0.9 \\
\hline 5 & 0.82 & 12.3 & 0.57 & 8.1 & 0.24 & 1.8 & 0.31 & 2.3 \\
\hline
\end{tabular}

4）たとえば，金銅，維維誌 14，378（1958）；前田，大营， 河合, 高分子化学 16, 621 (1959). 
${ }^{\circ} \mathrm{C}$ で 2 分間熱処理し, $\mathrm{NaIO}_{4}$ 処理した後の膨潤度, 溶解度 は表 2 に示すとおりである。 表 2 の膨潤度と溶解度の関係 をプロットすると図1のよ5 に，それ艺れの試料の熱処理 温度によって決まる曲線であ らわされる。ここで $170^{\circ} \mathrm{C}$, $195^{\circ} \mathrm{C}$ の熱処理物は同一曲線 であらわされる。また，低熱 処理温度ではるちろんである が, $170^{\circ} \mathrm{C}, 195^{\circ} \mathrm{C}$ 高温熱処 理物でも，やはり重合温度に よって膨潤度，溶解度の差が みられ，低温重合物ほど膨潤 度は小さい。

次汇製膜温度を種々変更し た皮膜を種々の温度で熱処理 し, その $\mathrm{NaIO}_{4}$ 処理後の膨

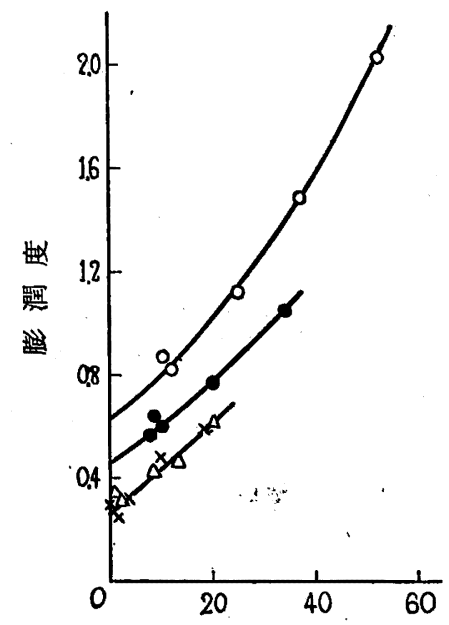

溶解度 $(\%)$

図 1 種々のPVA 皮膜の過ヨウ 素酸処理後の膨潤度と溶解 度との関係

制膜条件一定 $\left(30^{\circ} \mathrm{C}\right)$ 繁処理条件

$O: 120^{\circ} \mathrm{C}, \quad 1 \mathrm{hr} \quad \bullet: 140^{\circ} \mathrm{C}, 30 \mathrm{~min}$ $x: 170^{\circ} \mathrm{C}, 10 \mathrm{~min} \quad \triangle: 195 \mathrm{C}, 2 \mathrm{~min}$ 潤度，溶解度を測定した。製膜はいずれも $1.7 \%$ の PVA 水溶 液よりポリ塩化ビニル板上で行なった。製膜後は减圧デシケータ 一中で 2 日間放置してから熱処理を行なった。

その結果を表 3, 図 2 に示す。その結果膨潤度〜溶解度の関係 はそれぞれの試料の製膜温度および熱処理温度によって特徵づけ られている。しかも製膜温度が高くなるほど同一熱処理温度に括 ける膨潤度は小さくなる。これらのことは熱処理前にすでに存在 している微結晶によって熱処理による結晶化が決定されているこ とを示している。すなわち熱処理前に存在している微結晶はある 大きさと秩序度を有して括り，その度合によってある熱処理温度 に拈いて成長核となりうるものがきまる。したがって，その熱処 理盜度によって到達しうる繁結晶の結晶化は, 成長核の数によっ て決定される。製膜時の結晶化の過程は, 微結晶の発生とその成 長といら二つの過程が複合してあらわれるので，製膜温度が高い ほど分子運動は盛んであり，微結晶はつくりやすいが破壊される ものも多くて微結晶の数は少なく，熱処理によって到達する結晶
表 3 種々の製膜温度および熱処理温度の变化に 対する膨潤度と溶解度の関係

\begin{tabular}{|c|c|c|c|c|c|c|c|c|}
\hline \multirow{2}{*}{ 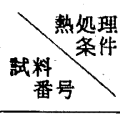 } & \multicolumn{2}{|c|}{$120^{\circ} \mathrm{C}, 1 \mathrm{hr}$} & \multicolumn{2}{|c|}{$140^{\circ} \mathrm{C}, 30 \mathrm{~min}$} & \multicolumn{2}{|c|}{$170^{\circ} \mathrm{C}, 10 \mathrm{~min}$} & $195^{\circ} \mathrm{C}$, & $2 \min$ \\
\hline & 此潤度 & $\begin{array}{l}\text { 溶解度 } \\
(\%)\end{array}$ & 微潤度 & $\begin{array}{l}\text { 溶解度 } \\
(\%)\end{array}$ & 跀潤度 & $\begin{array}{l}\text { 溶解度 } \\
(\%)\end{array}$ & 䏠潤度 & $\begin{array}{l}\text { 溶解度 } \\
(\%)\end{array}$ \\
\hline \multicolumn{9}{|c|}{ (i) $30^{\circ} \mathrm{C}, 5$ day } \\
\hline 6 & 2.48 & 55.9 & 1.25 & 38.4 & 0.60 & 19.8 & 0.47 & 14.9 \\
\hline 7 & 2.55 & 67.5 & 1.65 & 48.0 & & 24.2 & 50 & 18.9 \\
\hline 8 & 1.42 & 36.7 & & 25.3 & & 11.5 & 39 & 10.5 \\
\hline 9 & 1.43 & 30.4 & 0. & 20.8 & & 7.0 & 36 & 8.1 \\
\hline 10 & 0.98 & 15.4 & 0.72 & 10.1 & 0.34 & 2.9 & & 4.7 \\
\hline \multicolumn{9}{|c|}{ (ii) $50^{\circ} \mathrm{C}, 40 \mathrm{hr}$ 膜 } \\
\hline 6 & 1.64 & 47.0 & 0.88 & 32.6 & 0.55 & 19.5 & 56 & 23.4 \\
\hline 7 & 2.19 & 57.8 & 1.18 & 40.5 & 0 & 21.9 & & 22.4 \\
\hline 8 & 1.2. & 37.2 & 0.75 & 23.3 & 0.49 & 16.6 & 0.47 & 14.1 \\
\hline 9 & & 25.3 & 0 & 16.2 & & 8.5 & & 7.6 \\
\hline 10 & 0.94 & 16.2 & 0.53 & 9.7 & 0.34 & 7.5 & .43 & 8.7 \\
\hline \multicolumn{9}{|c|}{ (iii) $65^{\circ} \mathrm{C}, 22 \mathrm{hr}$} \\
\hline 6 & 1.52 & 35.2 & 1.12 & 36.2 & 0.57 & 26.6 & & 20.2 \\
\hline 7 & 1. & 33.0 & 1.33 & 38.3 & 0.59 & 20.2 & 0.50 & 19.0 \\
\hline 8 & 1. & 24.1 & & 19.6 & & 12.4 & & 13.0 \\
\hline 9 & 1.21 & 27.3 & 0.90 & 17.8 & 0.3 & 7.1 & 0.39 & 7.1 \\
\hline 10 & 0.84 & 8.9 & 0.66 & 9.5 & 0.32 & 3.1 & 0.29 & 2.2 \\
\hline \multicolumn{9}{|c|}{ (iv) $80^{\circ} \mathrm{C}, 17 \mathrm{hr}$ 膜 } \\
\hline 6 & 1.4 & 45.9 & 1.10 & 34.4 & 0.61 & 18.9 & 1 & 19.3 \\
\hline 7 & 1.92 & 55.0 & 1.16 & 37.1 & 0.5 & 21.8 & 7 & 22. \\
\hline 8 & 1.19 & 31.5 & 0.83 & 23.6 & 0.56 & 15.6 & 0.58 & 17.0 \\
\hline 9 & 0.87 & 21.9 & 0.63 & 11.5 & 0.37 & 8.4 & 0.42 & 4.8 \\
\hline 10 & 0.84 & 15.7 & 0.59 & 10.4 & 0.28 & 4.5 & 0.33 & \\
\hline
\end{tabular}

化はより十分になり，膨潤度す小さくなるものと考えられる。こ のことは次の実験によっても支持される。

$30^{\circ} \mathrm{C}$ で製膜したものをそれぞれ $65^{\circ} \mathrm{C} ， 1$ 時間熱処理，牤よび $100^{\circ} \mathrm{C}$ で 1 時間熱処理した後 $140^{\circ} \mathrm{C} て ゙ 30$ 分間熱処理したもの

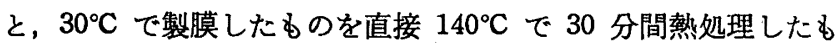
のについて $\mathrm{NaIO}_{4}$ 処理による膨潤度を測定した。その結果を裴

表 $4140^{\circ} \mathrm{C}, 30 \mathrm{~min}$ 熱処理物の前処理に よる膨潤度の差 (製膜, $30^{\circ} \mathrm{C}$ )

\begin{tabular}{|c|c|c|c|c|c|c|}
\hline \multirow[t]{2}{*}{$\begin{array}{l}\text { 前処理 } \\
\text { 条件 }\end{array}$} & \multicolumn{2}{|c|}{ 製膜後直接熱処理 } & \multicolumn{2}{|c|}{$\begin{array}{l}\text { 慗膜後 } 65^{\circ} \mathrm{C} \text {, } \\
1 \mathrm{hr} \text { 前熱処理 }\end{array}$} & \multicolumn{2}{|c|}{$\begin{array}{l}\text { 慜膜後 } 100^{\circ} \mathrm{C} \text {, } \\
1 \mathrm{hr} \text { 前愁処理 }\end{array}$} \\
\hline & 跀潤度 & $\begin{array}{c}\text { 溶解度 } \\
(\%)\end{array}$ & 埱潤度 & $\begin{array}{c}\text { 溶解度 } \\
(\%)\end{array}$ & 脚潤度 & 溶解度 \\
\hline 1 & 1.05 & 33.9 & 1.34 & 43.4 & 1.42 & 46.0 \\
\hline 2 & 0.77 & 19.9 & 1.22 & 33.8 & 1.05 & 30.5 \\
\hline 3 & 0.60 & 9.9 & 0.67 & 20.6 & 0.80 & 19.6 \\
\hline 4 & 0.64 & 8.7 & 0.61 & 5.9 & 0.67 & 7.6 \\
\hline 5 & 0.57 & 8.1 & 0.63 & 9.7 & 0.71 & 9.9 \\
\hline
\end{tabular}

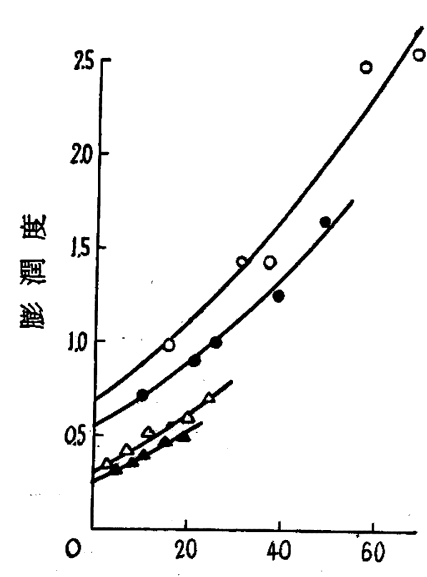

溶解度 $(\%)$

(i) $30^{\circ} \mathrm{C}, 5$ day 製膜

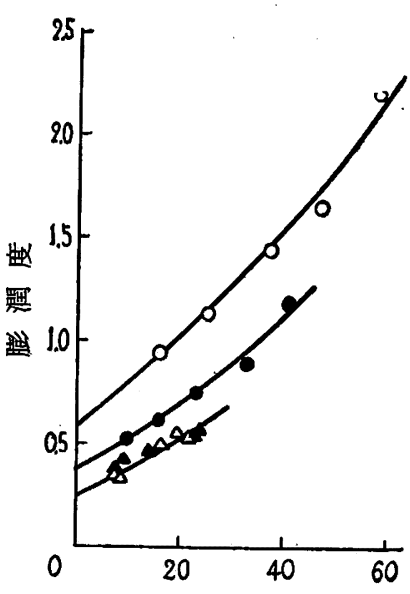

溶解度 $(\%)$

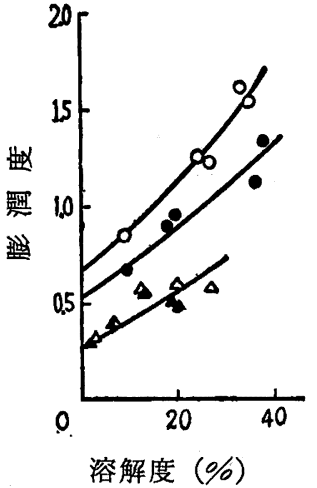

(iii) $65^{\circ} \mathrm{C}, 22 \mathrm{hr}$ 製膜

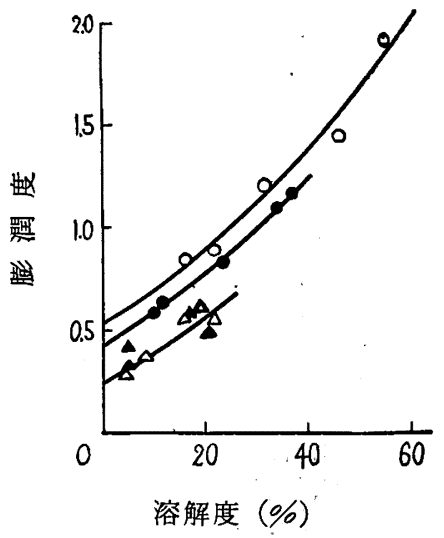

(iv) $80^{\circ} \mathrm{C}, 17 \mathrm{hr}$ 製膜

図 2 種々のPVA 皮膜の過ヨウ素酸処理後の膨潤度と溶解度の関係の製膜条件と熱処理温度による变化 繁処理温度 $\bigcirc: 120^{\circ} \mathrm{C}, 1 \mathrm{hr} \quad \bullet: 140^{\circ} \mathrm{C}, 30 \mathrm{~min}$

$\triangle: 170^{\circ} \mathrm{C}, 10 \mathrm{~min} \quad \Delta: 195^{\circ} \mathrm{C}, 2 \mathrm{~min}$ 
4 に示した。

前熱処理をしたものの方が膨潤度は大きくなり，かつ前熱処理 温度の高いものほど膨潤度は大きい。これは前熱処理することに よって熱処理時に有効な成長核の数が多くなり，したがって到達 する結晶化がより不十分となり，膨潤度が大きくなると思われ る。特に高温重合物においてその傾向が著しく，低温重合物では その差が小さくなる。

また低重合度 PVA の室温製膜物を $150^{\circ} \mathrm{C} ， 30$ 分間熱処理し $\mathrm{NaIO}_{4}$ 処理後の膨潤度を測定した結果を図 3，図4 亿示した。 低重合度 PVA についても重合温度 $60^{\circ} \mathrm{C}$ と $30^{\circ} \mathrm{C}$ のものについ ては図 3 に示すよ 5 に差が認められる。この場合重合時の溶媒の 影響についてはVAc を重合して低重合物を5る場合エタノール などを多量に用いたため明らかでない。 $\bar{P}_{\mathrm{A}}=500 \sim 600$ 以上では 重合度による膨潤度の差は認められない。膨潤度〜溶解度関係は $\bar{P}_{\mathrm{A}}=300$ 以下, $300 \sim 600$ 扎よび 600 以上の三つのグループに分 類される。

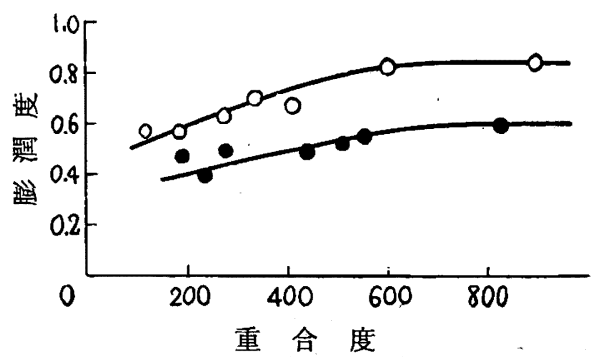

図 3 低重合度 PVA の重合度と膨潤度の関倸 $\mathrm{O}: 60^{\circ} \mathrm{C}$ 重合物 $\quad$ : $30^{\circ} \mathrm{C}$ 重合物

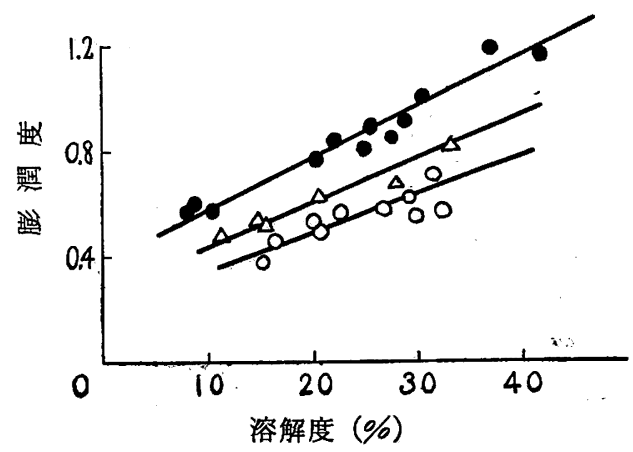

図 4 低重合度 PVA の膨潤度と溶解度の関係 O: $P_{\mathrm{A}}=300$ 以下 $\triangle: P_{\mathrm{A}}=300 \sim 600 \quad \bullet: P_{\mathrm{A}}=600$ 以上

また室温で製膜した未熱処理物の膨潤度は高重合度物にくらべ 低重合度物の方が大きいが，同一熱処理温度では熱処理効果が大 きいことは膨潤度の測定, 赤外吸収スペクトルの結果でも示され ている。熱処理皮膜の $\mathrm{NaIO}_{4}$ 処理による膨潤度の結果も同様で める。

この $\mathrm{NaIO}_{4}$ 処理による膨潤度〜溶解度の関係の 重合度による 差も熱処理がすでに存在している微結晶を核として成長が行なわ れると仮定するとよく説明がつく。すなわち低重合度物であるた め同一分子中に存在する微結晶の核の数は少なく，かつ分子間の からみ合いも少ないため高重合度物にくらべ熱処理によって微結 晶は十分成長し膨潤度は小さくなる。また低重合度物ほど同一膨 潤度に対し溶解度が大きく，膨潤度の增加に対する溶解度の增加 が大きいことは同一分子中に存在する微結晶が少ないことを逆に 示していると考えられる。
以上これまで述へててき実験事実はPVA の熱処理はその熱処 理条件において有効な既存の微結晶を核として成長が行なわれる と考えてよいと思われる。このことは長井ら ${ }^{5)}$ の赤外線吸収スペ クトルによる熱処理の研究結果とも一致するるのである。

また重合条件などによって左右される PVA の構造上の規則性 は製膜時の微結晶の核発生とその成長の両方に支配的であり, か つ熱処理時の微結晶の成長に有効に働くものと考兄られる。した がって同一条件で製膜したものの未熱処理物の膨潤度と熱処理物 の過ヨウ素酸処理後の膨潤度が常に一致した傾向を有し，かつ同 一条件で製膜しそれを同一条件で熱処理したものの過ヨウ素酸処 理による膨潤度はそれぞれの PVA の構造上の規則性と平行し た関係にある。

つぎに一般に膨潤度の測定結果は結晶化度と微結晶の分布に支 配される。PVA の高温熱処理物では高度に結晶化され, 非晶領 域でもかなり強固な分子内水素結合を有しているであろろし, 非 晶領域の平均鎖長も减少し結晶領域るかなり大き成長している ため膨潤による非晶領域の分子鎖の引きのばしに対する抵抗はか なり大きく，試料による純水中の膨潤度の差は激減する。しかし

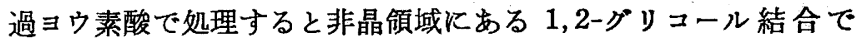
PVA は分裂され膨潤エントロピーは増大し膨潤度は増大する。 このことは種々の重合条件で生成した $150 \sim 160^{\circ} \mathrm{C}$ 以上の熱処理 PVA 皮膜の $30^{\circ} \mathrm{C}$ 純水中の膨潤度は差がないが過ヨウ素酸で処 理した後の膨潤度は增大し，しかも試料による差が認められると いうこれまでの実験結果で明らかである。また前述の微結晶の核 間距離によりその熱処理に扣いて到達する結晶化が決定されるこ となどから過ヨウ素酸処理後の膨潤度, 溶解度は微結晶の長さ, したがってその発生状態と特に密接な関係があり, かつラテラル オーダーの間接的な目安になるのではないかと考える。このこと に関してさらに定量的に検討してみよう。

ささに高柳6) は結晶性高分子の熱処理温度と結晶化度の関係式 を熱力学的に誘導した。この場合結晶化した高分子の構造を, 一 つの結晶領域と一つの非晶領域を組合わせたるのを構成単位とし て，既存クリスタリットの長軸方向の成長によって熱処理による 結晶化が進行するすのと簡単に仮定し次式を得た。

$$
\begin{aligned}
& \Lambda_{a}=K+\Theta \frac{\Lambda_{a}}{T} \\
& K=\frac{\alpha \cdot R}{m \cdot X_{u} \cdot S_{u}}
\end{aligned}
$$

ここで $\Lambda_{a}$ は乾熱処理に打ける最終非晶領域量, $T$ は熱処理 温度 $\left({ }^{\circ} \mathrm{K}\right), K$ は $(2)$ 式で示される定数で, $m$ はクリスタリッ

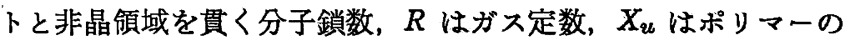
構造単位で示したクリスタリット中心間の鎖長, $S_{\boldsymbol{u}}$ は構造単位 $1 \mathrm{~mol}$ 当りの融解エントロピーである。なお $\boldsymbol{\alpha}$ は熱処理時にお ける分子鎖の拘束に関する定数であり， $\Theta$ は2 次転移点 $T_{g}$ よ り低い特性温度で分子鎖が完全に凍結される温度である。（1） 式より $\Lambda_{a}$ と $\Lambda_{a} / T$ の間注線関係が成立する。

過ヨウ素酸処理後に扣いて結晶領域に足場を有しない部分は溶 解し去るであろらから， いま $\Lambda_{a}$ として溶解度の值を用い $\Lambda_{a}$ と $\Lambda_{a} / T$ の関係を求めた。その結果の一例は図 5 に示すように

5) 長井, 美馬, 栗林, 相根, 高分子化学 12, 199 (1955).

6) 栗山, 高柳, 九州大学生産科学研究所報告 特別号 p. 33 (1957 年 3 月). 


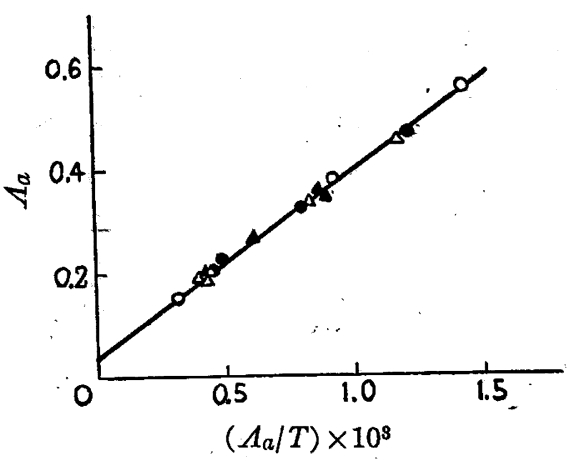

図 5 PVA $\left(60^{\circ} \mathrm{C}\right.$, 塊状重合) の熱処理に 対する $\Lambda_{a}$ 対 $\Lambda_{a} / T$ の関係

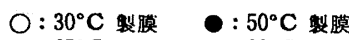

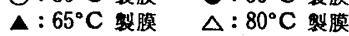

極めて良好な直線関係が得られ，これより $\Theta, K$ が求められる。

（1）式で $K$ は同一ポリマーで $\alpha, S_{u}$ が定数ならば $1 / m X_{u}$ に比例し, $m X_{u}$ は 1 個のクリスタリットを含むポリマーの量を 示すので $1 / m X_{u}$ はポリマー単位量中のクリスタリット中心核の 存在濃度にあたり，したがって $K$ は結晶と非結晶の 2 相構造が 完成する場合のクリスタリットの発生頻度の尺度と考えられる。 しかしこれについては少し吟味する必要がある。すなわち $\alpha$, $S_{u}$ を定数と考えるのに問題があり，同一種のポリマーですその 構造の規則性などによってその分子運動の模様が異なり，したが って $\alpha$ あ異なってくるであろう。また同一試料です核発生の頻 度が異なればそれによって受ける熱処理効果は異なっており，こ のよ5な場合 $\alpha, S_{u}$ も当然 $X_{u}$ の関数として考虑されねばなら ない※1。 $K$ の值は総括して $X_{u}$ に関する関数として取扱 5 べ であり，そしてそれがすなわち LO 分布に対応するすのと考え られる。これは上述の $\Lambda_{a}$ の値として溶解度をとり $\Lambda_{a} \sim \Lambda_{a} / T$ をプロットする場合図 5 に示すように製膜温度には無関係に同一 直線であらわされるが，各熱処理温度に和けるおの括のの膨潤度 が異なっている点で示される。次に同一 PVA をある条件で乾 式紡系した未延伸系 A,B について各温度で熱処理し, 前述と同 様な方法で過ヨウ素酸処理後の溶解度を測定し， $\Lambda_{a} \sim \Lambda_{a} / T$ の関 係を求め図 6, 表 5 认示した。直線関係は熱処理温度の高い部分 と低い部分の 2 直線にわかれ屈曲点が存在する。屈曲点となる温 度を $T_{\mathrm{c}}$ として示した。この屈曲点 $T_{\mathrm{c}}$ を境として直線関係が

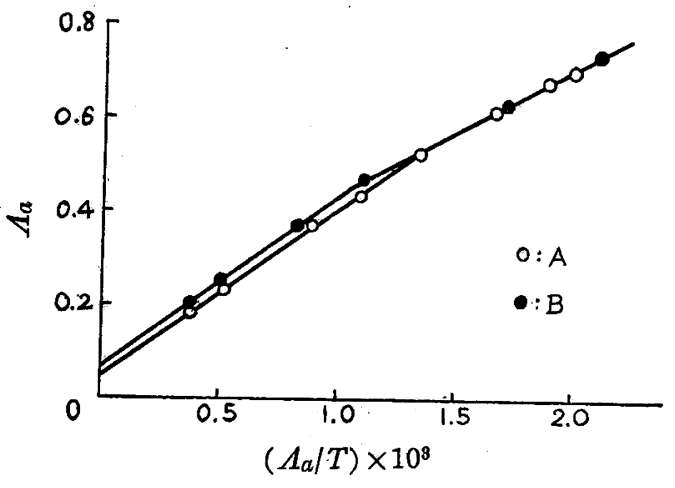

図 6 末延伸系 A，B の熱処理に対する $\Lambda a$ 対 $\Lambda_{a} / T$ の関係

※1 最近各種のポリエチンンについて融解エントロピーが測定 された [B. Ke : J. Rolymer Sci. 42, 15 (1960)]。それ によると Marlex-50 は通常の高圧法ポリエチレンにくら ベ融解ェントロピーは大きい。
表 5 末延伸系の定数 $K, \Theta, T_{\mathrm{c}}$ の数值

\begin{tabular}{|c|c|c|c|c|c|}
\hline \multirow{2}{*}{ 壾料 } & \multicolumn{2}{|c|}{ 低 温 側 } & \multirow{2}{*}{$T_{\mathrm{c}}\left({ }^{\circ} \mathrm{K}\right)$} & \multicolumn{2}{|c|}{ 高 温 㑡 } \\
\hline & $\overparen{K_{1}}$ & $\overline{\theta_{1}\left({ }^{\circ} \mathrm{K}\right)}$ & & $\overline{K_{2}}$ & $\overline{\theta_{2}\left({ }^{\circ} \mathrm{K}\right)}$ \\
\hline A & 0.16 & 266.5 & 393 & 0.04 & 365 \\
\hline B & 0.16 & 266.5 & 427 & 0.05 & 375 \\
\hline
\end{tabular}

分離するのは $T_{\mathrm{c}}$ の温度以下で非晶領域の分子鎖に加えられて いたある種の束縛が $T_{\mathrm{c}}$ に打いて解放されたためと解される。こ のことはすでに高柳的によって指摘されているが $K$ の值が低温 側で大きくなる，すなわち束縛定数 $\alpha$ が大きくなることとる一 致する。また系 $\mathrm{A}, \mathrm{B}$ の両者が低温側の $K, \Theta$ 值すなわち $K_{1}$, $\Theta_{1}$ は全く一致するが高温側の $K_{2}, \Theta_{2}$ はB $\mathrm{B}$ 方が大であり，ま た $T_{\mathrm{c}}$ 值も $\mathrm{B}$ の方が高い。 野原》)の核磁気共鳴の 結果によれば $75 \sim 140^{\circ} \mathrm{C}$ の温度過程は分子内水素結合をもった rod like な分 子鎖のその軸の回りの内部回転が温度とともに活発になる温度域 であり，150 $\mathrm{C}$ 以上で急に起る転移は結晶内部回転転移である5 と推論しているが，この転移する温度が $T_{\mathrm{c}}$ に対応するすのであ ろうと考号れる。したがって $T_{\mathrm{c}}, K_{2}, \Theta_{2}$ が B の方が大なる ことは非晶領域に甜ける分子鎖はより剛直な形態をとって扣り， 熱処理温度が比較的低い間は分子鎖の運動がより阻害され，結晶 化がさまたげられているのであろう。このことは同一熱処理温度 に括ける溶解度はBの方がAより常に大きいことで示される。ま た十分に有効な熱処理を行なわせるためにはBの方がより高い温 度を必要とするはずであるが，これは $\mathrm{A}$ 試料は $220^{\circ} \mathrm{C}, 2.5$ 分 の熱処理で紻維の溶着が括こるに対し B の方は $250^{\circ} \mathrm{C}, 1$ 分の熱 処理でもこのような溶着はみられなかった。

また $195^{\circ} \mathrm{C}$ の熱処理皮膜を過ヨウ素酸溶液に浸漬し，ポーラロ グラフによる過ヨウ.素酸の消費量の測定，および粘度測定を均一 な溶液中で反応したものと比較した結果は全く一致し，定量的に 1,2-グリコール量が反応することが明らかになった。

これらの結果および既報1で述べた結果を総括し，過ヨウ素酸 処理を施した PVA はその微細組織を適確に示している。これは 過ヨウ素酸処理によって PVA は非晶領域に存在している 1,2グリコール結合で分裂され孤立ミセル構造をとっていると考えて あ近似的佂正しいと考觉られる。

また Hess, Kiessig ${ }^{8)}$ や角戸，笠井9)および桜田，温品 ${ }^{10)} の$ $\mathrm{X}$ 線小角散乱の結果元られた大周期 $130 \sim 200 \AA$ ，または Hess， Mah111) の電子顕微鏡によるフィブリル軸方向の 133〜200 ̊ の 周期は，モノマー単位で 50〜80である。これは，これらの原料 PVA の 1,2-グリコール量は $1.8 \mathrm{~mol} \%$ 程度であり，1,2-グリ コール結合はモノマー単位で 50 個に 1 個の割合となるが，X線， 電子顕微鏡によってえられた周期とよく一致して招り，著者の見 解に有力な支持を与える。次に LO 分布を測定するためには， その凝集エネルギーに応じた分別溶解操作の前にあらかじめ連続 ミセル構造を構成している鎖状分子を切断して，孤立ミセル状態 にする必要がある。上に述べたように，過ヨウ素酸処理を施した PVA はこの条件を満足していると考えられる。すなわち PVA を過ヨウ素酸処理した後, フェノール溶液に浸漬すると,フェノ

7) 野原, 高分子化学 15, 105 (1958).

8) K. Hess, H. Kiessig, Kolloid-Z. 130, 10 (1953).

9）角戸, 笠井, 桜田編“ポリビニルアルコール” p. 223(1955), 高分子笑験化学講夾 2 巻, p. 96, 106 (1958).

10) 桜田, 温品, 高分子化学 17, 13 (1960).

11) K. Hess, H. Mahl, Naturwiss. 41, 86 (1954). 
ール溶液の溶媒和エネルギーより小さい凝集エネルギーを有する 頒域は非晶化されて完全な非晶領域となって溶解する。フェノー ル溶液の濃度を濃くして溶媒和エネルギーを大きくするとより高 いオーダーの領域も非晶化されて溶解度がます。このよ5な溶解 度の特性はその PVA の微細組織によって規定される。また 30 ${ }^{\circ} \mathrm{C}$ に扣けるブェノールの水に対する飽和溶解度は $8.75 \%$ である のでメタノール 20\% (容積) の各種濃度のフェノール溶液を用 いた。

すなわち試料約 $0.05 \sim 0.10 \mathrm{~g}$ ずつを $20 \mathrm{~m} . \mathrm{mol} / \mathrm{l}$ の過ヨウ素 酸ソーダ溶液 $10 \mathrm{cc}$ に $30^{\circ} \mathrm{C}$ で浸漬し, さらにこれに種々のフェ ノール濃度のメタノール 25\% 水溶液を加え， 24 時間浸漬後溶液 を流し出し純水で何回も洗浄し, さらに純水中に 24 時間浸漬す る。しかる後常法により溶解度, 膨潤度を求める。このようにし てフェノール濃度に対する溶解度の積分曲線を求め, これを図上 微分すれば LO 分布曲線がえられる。な欮述のようにフェノ ール濃度 0 の場合でも溶解する部分があるので, このような非晶 領域量とフェノール濃度の変化に応じて求められた LO 分布に

(i) $120^{\circ} \mathrm{C}, 60$ 分然多理

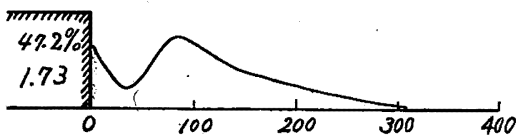

(ii) $150^{\circ} \mathrm{C}, 30$ 分焦名理

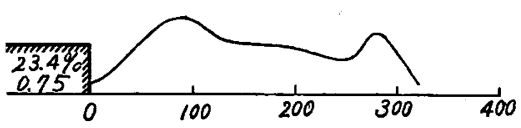

(iii) $170^{\circ} \mathrm{C}, 10$ 分热多理

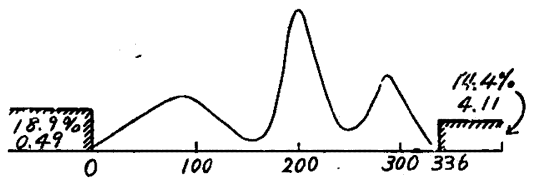

因 $7 * 50^{\circ} \mathrm{C}$ 製膜熱処理物の LO 分布

(i) $20^{\circ} \mathrm{C}$ 製脱

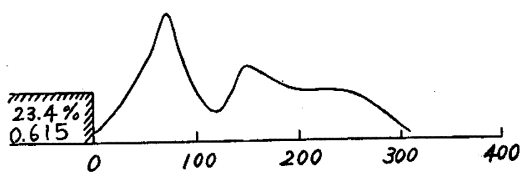

(ii) $50^{\circ} \mathrm{C}$ 製朕

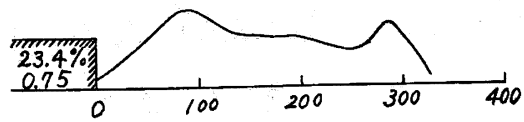

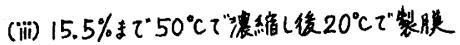

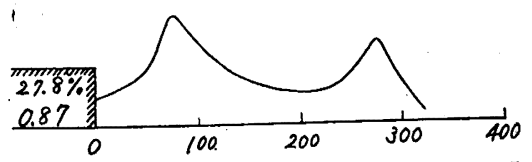

目 $8^{*}$ 製膜温度を䔬にする $150^{\circ} \mathrm{C}$ 熱処理物の LO 分布

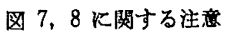

*1) 楼灲はフェノール湲度 $(\mathrm{g} / \mathrm{l})$

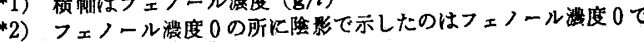
の溶解度 $(\%)$ 之㯕社度である。

*3) フェフール灌度 $336 \mathrm{~g} / \mathrm{l}$ (因 7 (iii)) 飞付した降影は $336 \mathrm{~g} / l$ での不溶解分 $(\%)$ とその脚潤度である。
よってその微細組織を検討せねばならない。

実験に用いた試料は重合温度 $60^{\circ} \mathrm{C}$, メタノール $20 \%$ 溶液重 合物 $\bar{P}_{\mathrm{A}}=1885$ である。製膜は $20 \mathrm{~g} / l$ の溶液より $50^{\circ} \mathrm{C}$ あるい は $20^{\circ} \mathrm{C}$, 湿度 $35 \%$ でポリ塩化ビニル板上にて行なった。熱処 理は空気浴中で行なった。得られた結果を図 7,8 K示した。こ の場合分別が重合度によるものでないことは表 6 K示すよ5

各フェノール濃度溶液中に抽り末 表 6 各種フェノール濃度 溶解分の粘度平均重合度を測定した 溶液に末溶解分の重合度 結果全く差がないことで確めた。

図 7 より製膜条件が同じ場合，熱 処理温度による変化をみると熱処理 温度が高くなるほど全体として高い オーダーの方にずれLO の分布は 鋭くなってくる。このことは熱処理

\begin{tabular}{|c|c|}
\hline $\begin{array}{l}\text { フェ } \\
\text { 濃度 }(\mathrm{g} / l)\end{array}$ & 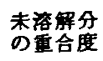 \\
\hline 0 & 204 \\
\hline 37.5 & 168 \\
\hline 75.0 & 172 \\
\hline 112.5 & 189 \\
\hline 150.0 & 189 \\
\hline 200.0 & 170 \\
\hline
\end{tabular}
が単純な既存クリスタリットの長軸方向の成長による非晶領域の 減少のみの過程でないことを示している。すなわち熱処理前に存 在している微結晶はある大きさと完全さを有しており, その度合 によって，ある熱処理温度において成長核となりうるものがきま り,このよ5な有効な既存微結晶の発達と再配列とが総合的に行 なわれたるのと解される。次に図 8 の製膜条件を变更させた場合 の差をみると, (i ) $50^{\circ} \mathrm{C}$ 製膜物の方が平均した LO は高く, (ii） $20^{\circ} \mathrm{C}$ 製膜物の方が低オーダーにおける分布が大きい。 た $50^{\circ} \mathrm{C} て ゙ ~ 15 \%$ 程度まで濃縮した後 $20^{\circ} \mathrm{C}$ で製膜した場合は, $50^{\circ} \mathrm{C}$ と $20^{\circ} \mathrm{C}$ 製膜物の中間的な LO 分布をもっている。これら のことは $20^{\circ} \mathrm{C}$ 製膜の方が微結晶の数が多く, 微結晶の間隔が短 かくて熱処理によって非晶領域へのしわよせが大きく, 結晶の成 長も不完全で, 小さな完全な結晶が数多く存在するため非晶部分 および低いLO 部分が多くなるものと考えられる。またこのよ5 に高温で製膜することが,（i）微結晶の核の生成数に支配的に なっているか, あるいは (ii) 微結晶核の成長に支配的になって いるのかという疑問が起る。これは製膜の過程における濃度時間 変化を考虑しなければならない。これらの点を検討するため, 試 料の $20 \mathrm{~g} / l$ の溶液を $50^{\circ} \mathrm{C}$ で種々の濃度に濃縮した後, それを

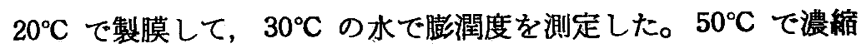
した際の PVA と膨潤度の関係をプロットしたのが図 9 である。 PVA 約 $20 \%$ 程度で膨潤度は最大となり以後急激に減少し, 30 $\%$ 以上ではほぼ一定となる。 $50^{\circ} \mathrm{C}$ で濃縮後 $20^{\circ} \mathrm{C}$ で製膜する場 合と，最初から $20^{\circ} \mathrm{C}$ で製膜する場合で異なるのは $50^{\circ} \mathrm{C}$ で濃樎 される過程のみである。濃縮温度が高ければ乾燥時間す短かく分 子運動は盛んであり，低温の場合にくらべその間に生成する微結

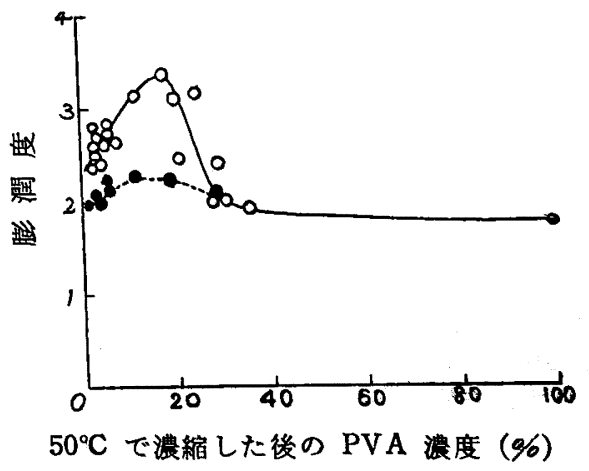

図 $950^{\circ} \mathrm{C}$ で濃縮した後の PVA 濃度と膨潤度の関保 
晶の数は少なく，また不規則なからみ合いで凍結された状態をと りやすくなる。これは濃樎される濃度が高くなるほどこの傾向は 強くなるが，ある濃度以上になると今度は核の成長が起り，かつ 凍結されている領域は再配列していく。これは $50^{\circ} \mathrm{C} て ゙$ 濃縮した すのを $20^{\circ} \mathrm{C}$ で製膜し，それをさらに $50^{\circ} \mathrm{C}$ で熱処理すれば図 9 に破線で示したよらに，膨潤度が減少することからも明らかであ る。この場合も 15〜20 g/l における膨閏度最大はやはりあらわ れる。すなわち，拈括さっぱにいってある臨界濃度以下までは核 生成の数を支配し，それ以上の濃度では核の成長を規定している のではないかと考元られる。図8の（i）と（iii）の差をみると後
者の方が LO 分布は鋭く，かつ最高の LO も高い。これは前述 の理由により熱処理時の有効微結晶の数が後者が少ないことで説 明できる。すなわら微結晶の数が少ないので微結晶間隔は長くな り，より完全な大きな結晶へと成長し，かつ非晶部分や低 LO 部 分も多くなるのであろう。

以上, 熱処理 PVA の微細組織をかなり具体的に明確にするこ とができるようになった。このような微細組織がいろいろな物性 と密接な関連をるつことは当然であるが今後の検討にまちたい。

本報告の発表を許可された会社当局に感謝する。

\section{ポリビニルアルコールヘのメチルメタクリレ゙ートのクラフト重合}

(昭 和 36 年 1 月 12 日 受 理)

井手文 雄*

ポリビニルアルコールを幹ポリマーとして，七リウム塩を開始剤に用いてメチルメタクリレートのグラフト重合を検討 した。

（1）触媒濃度に関しては重合率について極大值を示す曲楾関係がえられた。非常に低い触媒濃度においても，極めて 高い収率を示す。熱水抽出でえられた末反応ポリビニルアルコールの重合度は, 触媒濃度の增大とともに低下し, しかる その量も多いことから,ブロック重合の可能性が大きい。（2）幹ポリマーの重合度はグラフト重合に無関係である。 （3）セリウム塩は，ポリビニルアルコールを酸化して主鎖の切断を括こす。セリウム塩の濃度の增大とともに，ポリビ ニルアルコールの重合度は低下する。切断数とセリウム塩濃度との関係を求めた。（4）硝酸濃度の增大ととすグラフト 量は大きくなるが, 硝酸が存在しない場合は, ほとんどグラフト重合は進行しない。この点セルロースの場合とかなり異 なっている。（5）ポリビニルアルコール膜の結晶化度とグラフト量との関係を検討した。結晶化度の增大とともに，グ ラフト量は直線的に減少し,グラフトは非結晶部分に括こる。（6）ポリビニルアルコール-メチルメタクリレートグ ラフト重合物を、ピリジンと無水酢酸のアセチル化㓮で完全にアセチル化を行ない, ポリ酢酸ビニル—メチルメタクリ レート重合物を合成し，その溶解性等を検討した。

\section{1 藉言}

セリウム塩を開始剤に用いてのグラフト重合については,すで に幹ポリマーとしてセルロースの場合には，いくつかの成果を報 告してきだ。本報では，水酸基をるつ高分子の一つとして，ポ リビニルアルコールヘのグラフト重合を追究した。

ポリビニルアルコールのグラフト重合は, セルロースの場合と 同様に，最近放射線特に $\gamma$ 線照射による研究がその中心をなし ているようである。たとえば，桜田ら゙は，ポリビニルアルコー ル膜を水の存在下でスチレン，メチルメタクリレート，アクリロ ニトリルなどの単量体を $r$ 線照射を行なって，多量のグラフト 重合物をえている。辻ら゙柱として $r$ 線照射によって, ポリビ ニルアルコール瀻維にスチレン, アクリロニトリル；メチルメタ クリレートなどのビニル化合物をグラフトして弾性や熱可塑性, その他の性質をあたえることができると報告している。

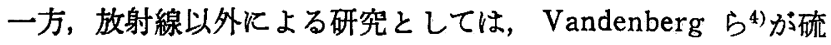

* 三菱レイヨン株式会社：東京都中央区京橋.

1) たとえば, 井手, 高山, 工化 64, 213 (1961).

2) 桜田, 岡田, 久語, 内田, Isotopes and Radiation 2, 296, $306,316,581$ (1959).

3) 辻, 北丸, 市場, 高, 工化 63, 1527 (1960).

4) E. J. Vanderberg, Wilmington, Del. U. S. P. 2, 837, 496 (1958 June).
酸の存在下で過酸化水素で酸化して，ヒドロペルオキシド基をポ リビニルアルコール中に導入して, グラフト重合を行なってい る。さらに桜田ら $5^{5}$ も， $r$ 線照射とともに，鉄イオンの存在下で す種々のビニル化合物がグラフト重合することをみとめている。

著者は, せリウム塩を開始剤に用いてポリビニルアルコールの 水溶液と膜についてのグラフト重合を行なった。水溶液の形での 重合は，極めて反応性にとみ，短時間で高収率でグラフト物をえ ることができた。しかし，セルロースの場合のように固体へのグ ラフト重合では, みられなかったセリウム塩の酸化によるポリビ ニルアルコールの主鎖の切断がみとめられた。

以下重合因子を中心に検討してえられた結果についてのべる。

\section{2. 実 験 方 法}

\section{$2 \cdot 1$ 試薬}

メチルメタクリレート: 酸性亜硫酸ソーダ飽和水溶液で, 次に 食塩水で洗ったのち, 水洗, 塩化カルシウムで脱水してイオウ華 の存在下で減圧蒸留を行ない，使用直前に再度蒸留した。 bp 45 ${ }^{\circ} \mathrm{C} / 95 \mathrm{mmHg}$ 。

ポリビニルアルコール：ポリ酢酸ビニルを 1 次, 2次ケン化を 行なったのち，常法どおりりに精製した。重合度 1040 。

硝酸セリウムアンモニウム：市販品をそのまま使用した。 5) 桜田, 岡田, 第 36 回ポバール会講演（昭和 34 年 11 月）. 